WARSZAWA 1986

Andrzej Musiał

\title{
ON THE MORPHOLOGY OF GLACIAL FORMATIONS OF NORTH-EASTERN POLAND. THE CASE OF THE BIEBRZA RIVER VALLEY
}

The Biebrza Valley represents in itself a vast physicogeographical unit lying between the old-glacial and early-glacial formations and extending over an area of more than 2.6 thousand $\mathrm{km}^{2}$. Along its northern border, starting from the outskirts of the country till the neighbourhood of Grajewo, one can follow the line of the Vistula glaciation confines. Here, there also stretch the Plain of Augustow and the Lake District of Ełk. South, east and west, the Biebrza Valley is surrounded by the old-glacial Uplands of Bialystok, the High-Masovian and the Kolno Uplands.

Because of its spatial position, the Biebrza Valley constitutes as such a clear-cut, major, concave macroform rather complex in its genesis, whose process of coming to what it is today has been truly long.

Many researchers pointed to the erosive origin of this form. In their opinion huge quantities of the Vistula's continental glacier thawing waters must have flown down this way in the southern direction. Accordingly, sands found in this area had to be interpreted as cumulative levels, or erosive and cumulative levels of glacio-fluvial origin, or as fluvial cumulation levels.

More recently views tend to prevail that the Biebrza Valley is older than once thought and represents in itself a remodelled depression of glacial origin(?), connected with the thawing-dead-ice situation. In H. Banaszuk's opinion (1980) even creviced and ablation-type forms of the older glaciations have persisted till this day.

Over the past two decades a great many geomorphological publications have appeared on the market, containing the description of forms found to occur in the Biebrza Valley and attempts to outline its origin and age. Little however has been written so far about geomorphological characteristics of the surrounding morainic uplands (the Białystok, High-Masovian and Kolno Uplands) with reference having been made in them to the Biebrza Valley. Such an approach 
gives more precision to conclusions drawn and helps to verify certain views as regards origin and age of the Northern Podlasie Region.

An accurate account of the Biebrza Yalley features, jointly with its division, is offered by $S$. Żurek $(1975,1983)$ and $H$. Banaszuk (1980).

Analysis of the relief of old-glacial morainic uplands in which the outskirts of the Biebrza Valley abound seems to univocally point to an ablation-type character of the region. Modelling of the glacial relief in the northern part of the Podlasie Plain is attributed to the Warta river continental glacier activity (Różycki 1978).

Quite specific spatial arrangement exhibits morphometric situation of the morainic uplands. The most outstanding heights exceeding 200 metres above sea level (their maximum height is $229 \mathrm{~m}$ above sea level) run meridionally. Most conspicuous is this relationship when seen on the example of the Sokołka Heights and elevations of the Kolno Upland. Culminations are situated some distance away from the Biebrza Valley, which causes that the said concave form appears as the lowest part of the vast depression in the morainic surface. Elevations occur in the form of tiny creviced forms, vast kame heights and morainic plateau (Musial 1983). Fractionally differing outwashes, with mostly coarse material found in them, take part in their building process. You can find there coarse-grained sand, boulders and gravels, with dark-coloured flints and large proportions of carbonate rock debris (chalk?) being also not uncommon. Often on slopes, and from time to time also on culminations, you happen to come across unveiling patches of the morainic clay. Material within the confines of elevations exhibits the signs of heavy dislocations, with perturbational forms being quite common among them.

Convex forms are reflected in the meridional valleys of the rivers Brzozówka, Sidra and Przytulanka. Astounding seems to be the fact that water runs here have an exceptionally „rectilinear" course. A similar orientation is evident in the case of the Slina River extending in the southern direction into the valley of the Tloczewka River.

Morainic elevations of the Białystok, High-Masovian and Kolno Uplands are shelving towards the Biebrza Valley to join it in steep slopes. Differences in height observed in this place exceed $20 \mathrm{mtrs}$. The analysis of the hypsometric map also indicates that there are a great many steep slopes within the uplands themselves, running in parallel at a certain angle to the Biebrza Valley line. A striking flexion in the relief forms is the Orlikowo-Obrytki slope north of Jedwabne, where the change in levels exceeds $70 \mathrm{~m}$. It stretches from north to south over a distance of more than eight kilometres 



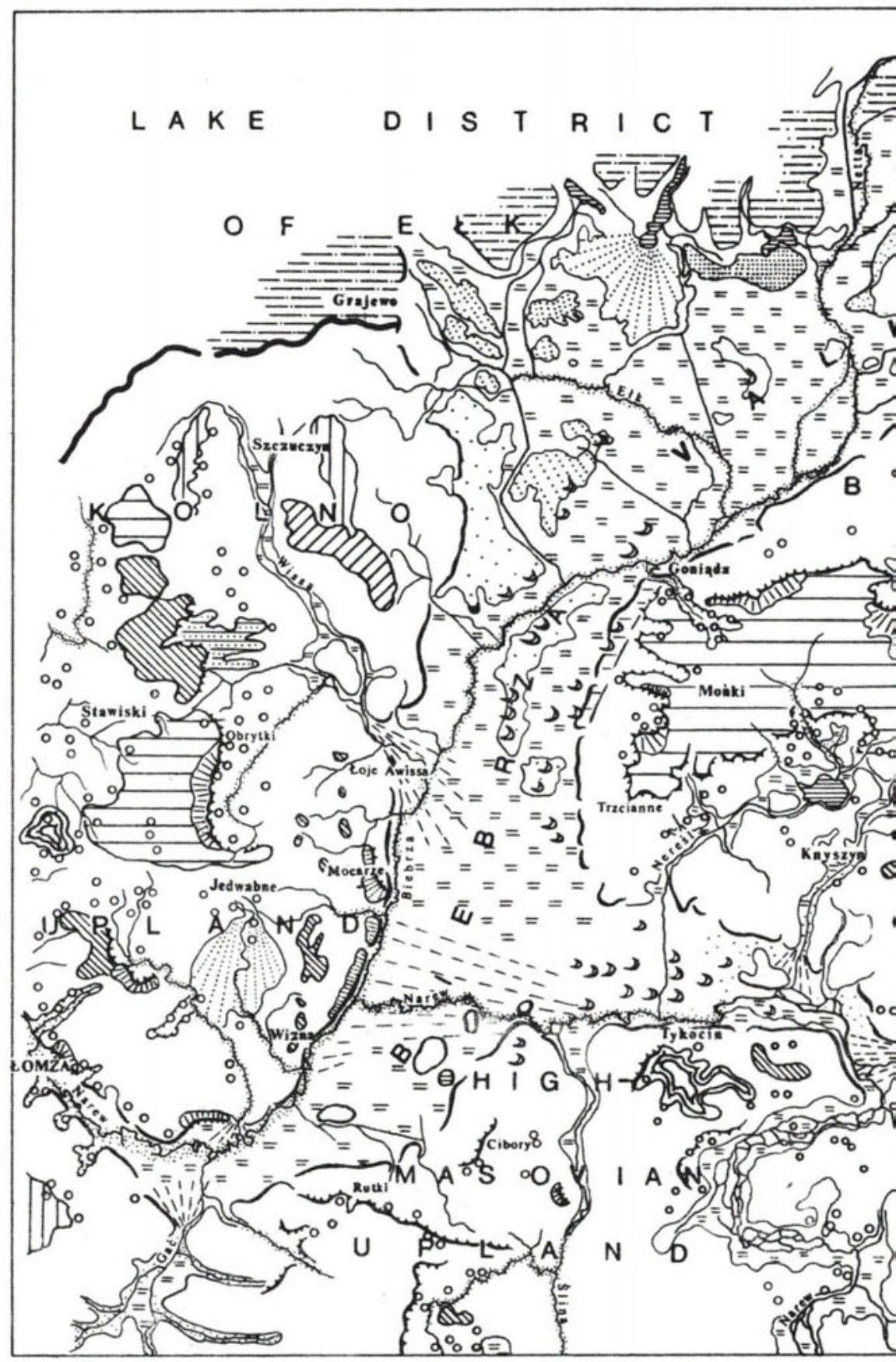

Fig. 1. The Biebrza Valley geomorphological outline against backgrou 1. The WARTA River glaciaton morainic elevations 2. Creviced form complexes 3. Mar 7. Glaciofluvial ablation cones (tali) 8. Outwash cches (tali) 9. Ablation heights and pla valleys 13. Ice coutact sopes 14. The Vistula River glaciation morainic upland 15. The slopes 20. Accumulation-characterized valley beds 21. Peat plains 22. Rivers and lakes 


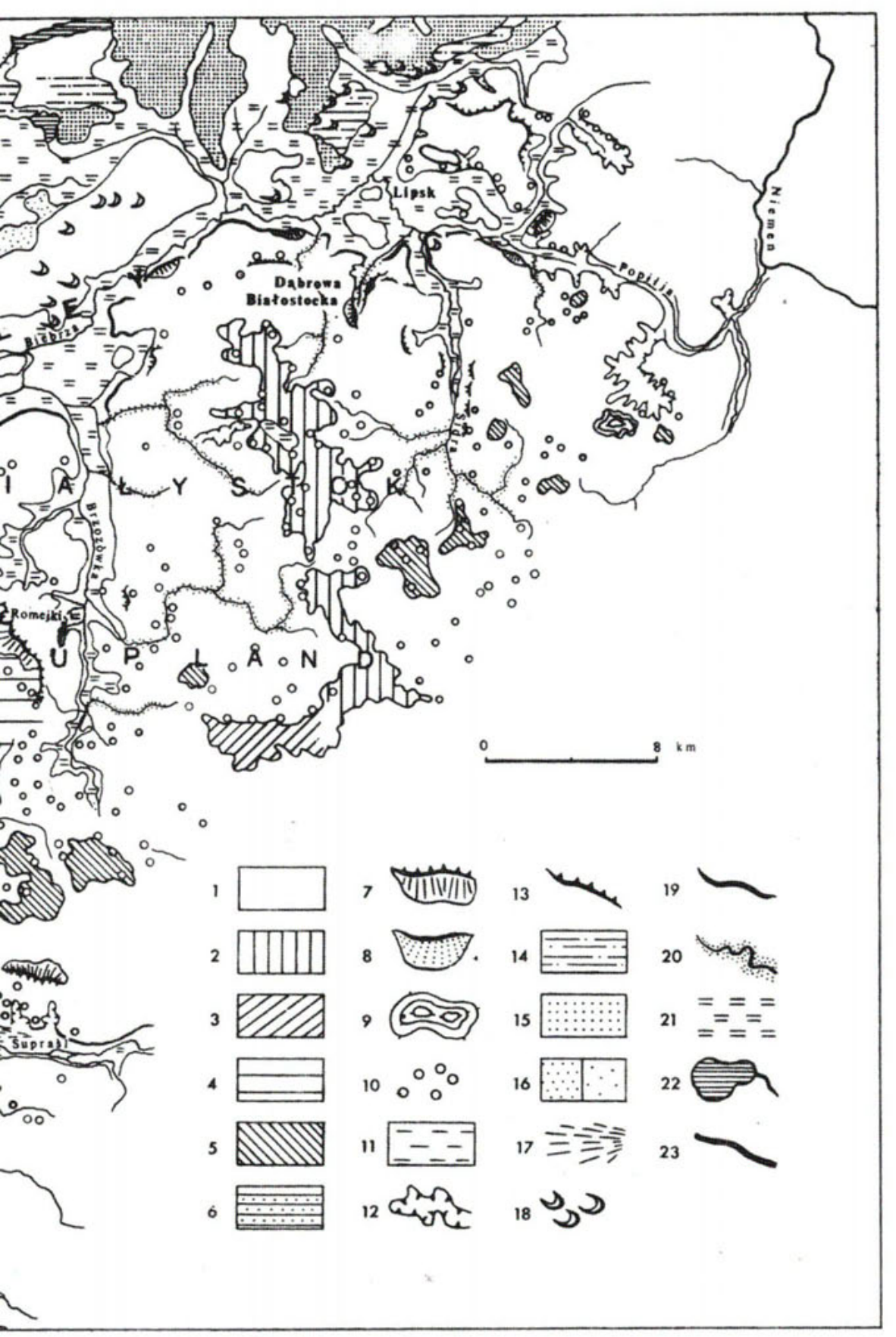

ad of adjoining territories.

ginal bank 4. Morainic plateau 5. Kame heights 6. Glaciofluvial ablation kame bank eaus 10. Areas in which small kame forms tend to occur 11. Erosion level 12. Melt-basin Augustów outwash 16. The Ełk outwash levels 17. Alluvial (tali) 18. Dunes 19. Upland 23. Line of the Vistula glaciaton 

and has a parallel position in relation to the Kolno Upland declivity. A similar NW-SE slope is found to exist near the village of Rutki. It closes the valley in its southern part to continue then in the eastern direction.

Meanderings readable in the landscape and stretching over a distance of some kilometres can be traced south of Goniądz and in the neighbourhood of Romejki, as well as north of Lipsk along the rivers Sidra and Brzozówka. Shorter slopes with a smaller change in levels occur not far away from Mocarze in the Kolno Upland, near Cibory in the High-Masovian Upland, and close to Dąbrowa Białostocka. These meanderings are brought out through the presence of small radial forms connected with the dead ice and fail to be continuous in their character as occurring on different hypsometric levels.

Much more complex and intricate in their course are similar slopes identified in the Bialystok Upland. They form numerous ,bays" and "peninsulae".

Outcrops located within the confines of said slopes and in their nearest vicinity show sand and gravel to dominate in them as stock material. From time to time you come also across packets of the brown-red boulder clay. Attention is attracted by spatial diversification of fraction in the local deposits. Coarse-grained material prevails within the slopes and on surfaces near the edges. It abounds in cumulations of boulders and gravels. The further you go from the edge zone the smaller will be the fraction of deposits.

From the proximal side, the slopes, are accompanied by a specified set of forms. Items identified here include: hills, heights and kame banks-mostly glacio-fluvial in their character, groups of hills and heights of the dead ice moraines and the kame terraces. It is characteristic that the said forms, produced as a result of the process of deglaciation, are situated on various levels. This causes that conspicuous flattenings are observed within long slopes.

The above levelling of the relief, in the author's opinion, comes from the successive stages of decay of the continental glacier which once had covered these areas. In the near-edge zones of the said slopes there are glacio-fluvial ablation cones (tali) inclined a little on the side of depressions and extending over a distance in the neighbourhood of Obrytki, Goniądz, Romejki, Dąbrowa Białostocka. Most often, they are built of sand and gravels and flow-clays (in some places only). It is these forms in which you can best see diminution of outwash fractions the further you are away from the edges. There are a great many slopes that are complex in their morphology and differ in their appearance from the classical forms of this type. This results 
from the complex and intricate conditions of accumulation prevailing near the ice edges.

The described slopes found in the old-glacial elevations of North-Eastern Poland and representing a well-identifiable landscape feature must be qualified as ,ice contact”. slopes. Many similar meanderings used to be regarded so far as proximal slopes of the terminal-moraine forms. However, the spatial analysis of these slopes univocally indicates that they coincide in their shape with that of the Biebrza Valley and major river valleys entering it, such as e.g. Brzozówka and Sidra. They form therefore as if a framing of the melt-down basins now used by these rivers, delineating at the same time contours of the ice at a certain stage of its deglaciation.

Some confirmation for the melt-down character of the Biebrza Valley entourage relief is provided by groups of concave forms that have developed between Goniądz and Trzcianne. These are vast depressions opening into the valley. Some of them have the form of small melt-down valleys, as e.g. those of Sidra and Brzozówka; others form circular amphitheatres, as e.g. the melt-down basin of Kosotka south of Goniądz. The bottom of this concave form passes away into the lower level of the upland and remains suspended in relation to the Biebrza Valley level. Within its confines one can find several forms of the flat-topped hills and dead ice.

Another type of the melt-down spots is represented by valleys with a set of lateral kame forms and dead ice moraine hills identified east of Lipsk on the Biebrza River entering right into the valley. On the other hand, north of Knyszyn there is a vast melt-down basin resembling a circle and dewatered these days by the Nereśl River.

Elevational areas, to which a part of the outwash land refers, represent a terrain hypsometrically little diversified. Most land is occupied by them in the Białystok Upland (from the Brzozówka river mouth to Goniądz). In the Kolno Upland they stretch from the village Eoje Awissa to Wizna, while in the High-Masovian Upland they are found west of the Slina River.

These areas that extend within the peripheral parts of the uplands and accompany the valley have been described as the erosion and cumulation levels (Bałuk 1982).

In the light of data gathered, this is denied by the presence of kame type dead ice forms and dead-ice-moraine hills as well as glacio-fluvial and ablation cones (tali) within the confines of the areas discussed. The land extending along the eastern slope of the Kolno Upland shows also a conspicuous inclination on the Biebrza Valley 
side, which is a proof that the thaw-waters tend to flow from east to west and not from north to south.

Another record of the episodes connected with the process of deglaciation are also plains built of silts, found in the vicinity of the slope of upland surrounding the valley. Outwash of this type has been proved to occur in its eastern peripheries around Knyszyn and Goniądz, and in the west near the town of Wizna. Silty deposits fill up mostly upper sections of the valleys and happen to represent sedimented formations where the ice used to contact land, in the so-called lateral reservoirs.

The analysis of the relief illustrates that modelling of the uplands in the direct vicinity of the Biebrza Valley used to proceed under conditions of a far-advanced process of deglaciation. This, among other things, had its reflection in the following events:

- in the pattern of the distinctly marked ice contact zones which reprint the valley contours;

- in the configuration and location of the kame forms and dead ice moraine hills as well as glacio-fluvial and ablation cones (tali); valley;

- in the spatial situation of the outwash valleys opening into the

- in the facial configuration of the outwash deposits incorporating forms produced during the deglaciation phase.

Considerations developed herein help us to reproduce certain mechanisms linked with the decay of the Pleistocene ice cover in North-Eastern Poland.

Deglaciations in the territory under discussion must have been area-oriented in their character. The first to have been freed from ice were the highest elevations. As the thawing fragments used to increase in their size, increasingly lower morphological levels separated by ice contact slopes tended to come into the scene. Groups of kames and hills of the dead ice moraines were formed along these lines.

In the continuing process of the continental glacier's degradation there had to be seen contours of the melt-down basins in which you can find today valleys being, in fact, beds of the major rivers. They were filled with ice which continued to remain longest unthawn in the depression of the today's Biebrza valley formation.

The way of the ice cover decay as described herein makes it possible to distinguish a separate type of glaciation which we might refer to as a ,fragmentary type deglaciation”. Around the initial forms having evolved within the thawn-in fragments there used to appear successive morphological levels along with complexes of the glacio-fluvial and ablation forms. 


\section{REFERENCES}

Bałuk A., 1982. „Varying Deglaciation Processes on the Lower and Middle Narew River during the Middle-Polish Glaciation", Bull. Inst. Geol. 343, vol. V, Warszawa.

Banaszuk H., 1980. „Geomorfologia południowej części Kotliny Biebrzańskiej" [Geomorphology of the Southern Part of the Biebrza Valley], Prace $i$. Studia Geograficzne, vol. 2, Warszawa.

M usia 1 A., 1983. Rozwój rzeźby glacjalnej Wysoczyzny Kolneńskiej [Development of the Kolno Upland Glacial Relief] PWN, Warszawa.

Różycki S. Z., 1978. „Od Mocht do syntezy stratygrafii plejstocenu Polski” [From Mochty to the Synthesis of Poland's Pleistocene Stratygraphy], Rocznik Polskiego Towarzystwa Geologicznego, vol. 48, No. 3-4, Kraków.

Zurek S., 1975. "Geneza zabagnienia pradoliny Biebrzy" [Origin of the Biebrza Stream Valley Marshes], Prace Geograficzne PAN, No. 110, Warszawa.

Zurek S., 1983. "Charakterystyka geomorfologiczna basenu środkowej Biebrzy" [Geomorphological Characteristics of the Middle Biebrza Basin], Zeszyty Problemowe Postępu Nauk Rolniczych, No. 255. 